Submitted: 14.11.2021 - Accepted: 21.12.2021

Year: December 2021 - Volume: 2 - Issue: 2

DOI: $10.47333 /$ modernizm.2021273785

\title{
MODERN DIRECTIONS OF A TRADITIONAL ART: THE USE OF COLOUR IN JAPANESE CALLIGRAPHY
}

\section{loana-Ciliana TUDORICĂ ${ }^{1}$}

\begin{abstract}
This study aims to analyse the way in which modern techniques are used in the art of Japanese calligraphy (shodō). Known for its preservation of traditional values, over the years shodō has started to focus less on rigour of the form and more on the possibility to reflect the calligrapher's vision and thoughts. The article intends to highlight this shift by accentuating the impact that the evolution of writing in Japan has had on shodo and ultimately showcasing the way in which colour is used by calligraphers. The two aspects this study will bring forth will be the way in which the evolution of writing in Japan created an opportunity for innovation and how the novelty factor has evolved, currently opening new possibilities of using colour to convey deeper layers of meaning. In order to illustrate how the use of colour in shodō can transcend conventional practices, we analyse the work (物の)哀 The beauty of simple and ephemeral things created by the contemporary Romanian calligrapher Rodica Frentiu. We conclude by emphasizing the close link between traditional values and the calligraphers' expressivity and by underlining the fact that this approach can broaden the creative horizons of shodōin the future.
\end{abstract}

Keywords: Shodō, Japanese Calligraphy, White Space, Yohaku, Mono No Aware, Transcendent Meaning

\section{INTRODUCTION}

Shodō is a practice characterized by duality on different layers, as it requires discipline and patience in order to master the techniques passed down from generation to generation, but also creativity that distinguishes the calligrapher's work from others in the field. These two aspects have led to shodo keeping its core values and writing techniques intact over the course of time, yet constantly evolving in order to meet the needs and the perspective of the calligraphers in the modern age.

Moreover, as far as the visual aspect is concerned, shodo traditionally uses only the black of the ink and the white of the paper, the only colour added being the red of the master's seal. When it comes to the purpose of the art, shodo has two main functions: beauty (美, bi) and utility (用, yō) (Hirakata et al. 90), as a calligraphic work is simultaneously an aesthetically impactful manner of conveying deeper views and a means of purification through self-discipline and intense focus, of getting in touch with the inner

\footnotetext{
${ }^{1}$ PhD candidate, Babeş-Bolyai University, Asian Languages and Literatures, ciliana.tudorica@yahoo.com, ORCID: 00000002-1381-4412
} 
and outer world for both the practitioner and the public who admires the work. In order to achieve these two functions, the calligrapher needs to constantly balance both creativity and discipline. The delicate mix of tradition and innovation in shodo has changed over the course of time, in the present age leading to intriguing calligraphic works that showcase modern writing techniques and the calligrapher's thoughts while honouring the tradition of writing.

\section{Concepts}

In examining the relationship between tradition and modernity in shodo, the article will employ several concepts, such as white space, the 5 main types of shodo calligraphy and the concept of transcendent meaning coined by Jean-Jacques Wunenburger.

For a better understanding of the composition of shodo, we propose identifying two elements within a calligraphic work: a linguistic component (the word, phrase, expression or text written) and a visual component (the way in which the linguistic component has been represented). Both components are crucial for a calligraphic work, as a shodō piece without a linguistic component becomes abstract art and without the visual component it remains mere writing. Even if the calligraphic techniques become more creative, sometimes even extravagant, the essence of shodo remains unwavering, as each calligraphic work preserves the two components that define the art of writing: a linguistic component and a visual component.

In analysing the visual component of a calligraphic work, the 5 main writing styles can become an important tool. Tensho, reisho, kaisho, gyōsho and sōsho have been passed down from generation to generation, a calligrapher being knowledgeable of each of the 5 styles. Tensho and reisho styles are relatively rarely used in calligraphic works - tensho could originally be found in inscriptions, stone tablets or monuments and the reisho style was influenced by tensho, considered an easier form of it, being particularized by precise, clear lines with extensions at the beginning and the end of the strokes (Sato 18). The most common style of writing is the kaisho style, which can be found in manuals, dictionaries and books. Literally meaning "correct style" (Sato 19) this style is characterized by clarity of form and legibility. Because of its familiarity, many shodō practitioners start by learning kaisho. However, this style is one of the most restrictive ones as far as calligraphy is concerned, as each stroke must be carefully written, the calligrapher not having much freedom in altering the form of the characters. When it comes to freedom of expression, however, the semi-cursive gyōsho style and the cursive sōsho style allow the calligrapher 
to create dynamic works in which the shape of the characters does not have to accurately represent the conventional ways of writing. When using gyōsho and particularly sōsho, the calligrapher creates a fascinating balance between the flow of line and the active empty space (Sato 19). For this reason, many calligraphic works are written in either gyōsho or sōsho style, or a variant of them.

Each writing style creates a different visual effect, in which the black ink and the white of the paper play an important role. Within this article, the white space and black ink refer to the visual elements present within a calligraphic work, namely the black of the ink used to write the characters and the white space of the rice paper. As shodo is a form of art that traditionally does not use colour, in most works the only colour present is the red spot marked by the calligrapher's seal. In spite of the apparent chromatic simplicity of a calligraphic work, shodo does not deny the role of colour, but rather finds new ways to reflect it. This article aims to analyse the importance of colour in shodō and how modern artistic trends can challenge the traditional view, revealing new meanings.

The concept of transcendent meaning will be used in the current study referring to Wunenburger's dual characterization of meaning of an image: immanent meaning and transcendent meaning (Wunenburger 250). The transcendent meaning is specific to images with a complex informative load, requiring an elaborated interpretive approach in order to be able to access it (Wunenburger 250). The transcendent meaning is ubiquitous in art, becoming the key element through which a work of art has left its mark on the one who interprets or contemplates it. This type of meaning is never communicated clearly and integrally (Wunenburger 257) and it is only accessible by connecting several existing meanings both inside the work and outside it. For this reason, in the interpretative process of shodo, accessing the transcendent meaning reveals to the receptor hidden meanings that uncover deeper layers of the calligrapher's perspective.

\section{From Rigour to Self- Expression}

The process of discovering the self through shodo and shifting the focus towards calligraphic works that convey a calligrapher's unique view of the world has been - and continues to be - a long, compelling process to which various factors (such as the evolution of writing, socio-cultural changes, globalization, the influence of spirituality and religion) have played an important role. In this study our focus will be on the ways in which the calligrapher can restructure traditional values, showing the evolution of shodo from both a 
linguistic (the way in which changes in the system of writing created shifts in shodō) and a visual perspective (how colour is used and perceived in shodō).

Similar to how the writing system based on kanji logograms has been borrowed from China around the $5^{\text {th }}$ century (Davey 217 ), the art of writing has also been one of the elements of Chinese culture that came to Japan and was later developed to meet the needs of Japanese calligraphers (Davey 219, Sato 12, Suzuki 6). Shodo evolved parallel to the changes in the Japanese writing system, from the borrowing of Chinese kanji logograms to the appearance of the hiragana and katakana syllabaries. Thus, writing and Japanese calligraphy have always been in a relationship of interdependence, nowadays the two still maintaining a close connection. One of the first big steps towards innovation that set Japanese calligraphy apart from the Chinese model was the creation - and the use - of the hiragana and katakana syllabaries within a calligraphic work. As a result, when it comes to the linguistic component of a work, there are 3 main types of shodo depending on the writing system used, each type allowing the calligrapher to illustrate different aspects of the written word: calligraphy written in kanji, kana calligraphy and calligraphy that uses a mix of kana and kanji.

From a linguistic point of view, the writing system chosen to create a calligraphic work can be the differentiating factor and the element that sets the tone and the nature of the emotions transmitted. Calligraphy using kanji logograms is practiced by both masters and beginners. The hiragana writing system is not used in this style, kanjicalligraphy being rooted in the Chinese tradition. Visually, this style can have a strong impact due to the logographic aspect of kanji. Therefore, a receptor who looks at or analyses the work can easily reach the meaning that the calligrapher wanted to convey. This type of calligraphic works often consists of a single written word, sometimes a single kanji logogram, a word containing two or more kanji, or an idiomatic expression based on the Chinese writing system. This illustrates the linguistic and semantic power of a word: computer-written, the word 無 (mu, "nothing, void") does not have as much emotional charge as a brush-written calligraphic piece that reflects the same word imbued with the calligrapher's perception of its meaning. Through the visual-linguistic combination present within a calligraphic work, the calligrapher acquires the freedom to highlight a certain aspect of the word. Calligraphy therefore becomes an opportunity to transcend the common sense of words and provide the context that the receptor needs in order to understand new meanings of a word.

Upon borrowing calligraphy from China, shodō practitioners paid close attention to 
the traditional means of writing and closely followed the example of the masters. Over the years however, shodo started to slowly differentiate itself from Chinese calligraphy, an important aspect in this process being the creation of the kana syllabaries. Although both hiragana and katakana stem from kanji, they have integrated themselves into everyday writing, together with the use of kanji.

Hiragana was initially known as onnade ("woman's hand") (Murase 17, Suzuki 7, Seeley 78), as the syllabary was used by women in personal letters (official documents continuing to be written using Chinese characters) and in any kind of informal writing (Murase 17). The shape of the characters in the hiragana syllabary is characterized by rounded and harmonious lines, lacking the harshness and rigidity of the Chinese logograms written in rigorous styles such as kaisho. Katakana was initially used in order to clarify the readings of certain logograms from various official documents (Robinson 201). Currently, katakana is used to write neologisms and has an angular visual aspect, as opposed to the round features of hiragana. The creation of the hiragana and katakana syllabaries was a natural response to the requirements of the language and was an important step in finding a Japanese-specific calligraphic style.

Similar to the way in which the use of the kana syllabaries distinguished Japanese writing from Chinese writing, in shodō, kana calligraphy is an indicator of the unique types of Japanese calligraphy. Hiragana calligraphy is often made with a thin brush, unlike kanji, which, oftentimes, are written using a thick brush. Hiragana calligraphy therefore denotes a high degree of finesse and delicacy through the movement of the brush, the curvature and the thickness of the lines. Particular to the hiragana style is the renmentai technique (連綿体, “uninterrupted line") (Suzuki 58), a technique specific to Japanese calligraphy. Through it, the unification of the characters from a calligraphic work is achieved by using continuous brush movements, thus creating the impression of an uninterrupted line. In calligraphy, although when finishing writing a character the master lifts the brush from the paper, their hand shapes in the air a line that connects the already written character with the one that is about to be written. Through the renmentai technique, the calligrapher no longer lifts the brush from the paper, the connection between each character being transposed directly into the calligraphic work. Renmentai visually renders the connection between each character, notion and idea transposed through shodō in a fluid, delicate and dynamic manner.

As current Japanese writing uses a combination of both kana and kanji, shodo can 
also be written by combining the currently existing writing styles. This type of calligraphy becomes easier to read for the public and allows the calligrapher to write in a natural, organic manner. The combination of kanji and hiragana in shodōis known as chōwatai (調 和体, "harmonious script") (Earnshaw 2000: 96), being a unique way of writing calligraphy, which balances both the delicate aspect of hiragana and the complex charm of the kanji logograms.

As reflected by the close link between innovation in writing and innovation in calligraphy, the issue of individuality in shodo and the need for self-expression arose from the beginnings of the practice of calligraphy in Japan, when calligraphers gradually began to move away from the model offered by Chinese masters and find a specific Japanese style. This was initially possible by including in the works specific writing systems (hiragana and katakana) and Japanese aesthetics, thus becoming a new branch, different from Chinese calligraphy (Tingyou 117). Following the Second World War, under the influence of Western thought, this process was taken a step further, calligraphy increasingly focusing on the calligrapher's self and feelings (Flint Sato 50).

The one who prominently brought forth the perception of the line as a form of selfexpression was Hidai Tenrai, pleading to move calligraphy away from its educational function and emphasizing the importance of the line (Flint Sato 50-51) and the creativity of the calligrapher (Bogdanova-Kummer 14). With little to no focus on the linguistic component of a calligraphic work, avant-garde calligraphers wanted to free the act of writing from the linguistic component, bringing calligraphy closer to abstract art (Bogdanova-Kummer 15). Although the calligraphic avant-garde and the desire to internationalize shodō by rethinking writing conventions eventually led to this form of art returning to some of its traditional roots, the avant-garde being a period in which calligraphers tested and challenged the limits of writing (Bogdanova-Kummer 140), this period proved to be a very important one in the discourse of the connection between self and shodō. As a result, the calligrapher nowadays balances the traditional and the modern, the rules of writing and personal view, looking for new horizons and a personal style (Suzuki 11).

\section{The Perception and Use of Colour in Japanese Calligraphy}

The continuous process of innovation and the desire to look for ways to engrave fragments of the calligrapher's own thoughts and spirituality has led to various techniques which bring the art of shodo closer to modern calligraphic techniques. In the following 
paragraphs our focus will be on one of these techniques, namely the way in which colour is used and perceived in shodo and how calligraphic works can find ways to go beyond its traditional practice.

One of the techniques that define shodo as an art is the use - or rather the absence - of colour within a calligraphic work. In order to reflect a calligrapher's ideas, shodō uses only the black of the sumi ink and the white of the paper, as the only colour present is the red spot which indicates the calligrapher's seal. The simplicity of the practice does not limit the calligrapher's creativity, as this concept is closely linked to the Buddhist vision of emptiness.

Extremely relevant for Japanese spirituality, the absence, nothing becomes in calligraphy an important aspect, generating meaning. The Buddhist perception of nothingness is considerably different from how the West feels about this concept, as it does not have any negative connotations. The idea of nothing, emptiness in the Buddhist tradition is called śünyatā and was coined by the Buddhist philosopher Nāgārjuna (Abe 126). In Buddhist philosophy, this vision of emptiness is not a nihilistic one (Abe 126), on the contrary, it transcends nihilism (Nishitani 98) and incorporates existence in all its complexity, without denying it of any aspect. In art, the idea of emptiness appears as ma ( 間, "space, interval"), indicating a period of time in which seemingly nothing happens, yet these pauses become extremely valuable within the work (Ikegami, "Homology of Language and Culture" 398). As a result, in order to understand the final piece the receptor must take into account these moments of silence as well.

Similarly, in shodo, the unwritten white space has a crucial role in the overall structure of the work and is known as yohaku (Flint Sato 58). While Western calligraphy is a continuous process, each line being written steadily and the words written without interruption, gaining a linear quality (Mukai 67-68), in shodō interruptions, moments of silence are carefully and intentionally placed by the calligrapher to reveal meanings to the receptor which cannot be conveyed through ink. The white space thus becomes an "active" one (Flint Sato 55) and must be analysed together with the space filled with brush traces in order to reach what Wunenburger called transcendent meaning.

When trying to decode the message of a calligraphic work, the viewer will include in their interpretation every element of the work, including the white spaces that surround each written character. Yohaku is not a space that could not be used, but a space that 
must be activated (Flint Sato 55, Frențiu 59), the way in which the ink is placed thus having the role of enhancing the white space that surrounds it. In the analysis of a calligraphic work, one can say that yohaku ga ikite iru ("the white space is alive") or yohaku ga shinde iru ("the white space is dead") (Flint Sato 61), describing the dynamism of the work through the lens of the way in which the white space has been used. The white space is therefore just as important as the written word, the two coexisting in full harmony.

The concept of white space does not however refer only to the areas around the written characters or inside a character, between each constitutive brush stroke. White space can appear through the kasure technique, a technique in which the calligrapher deliberately works with a semi-dry brush, creating lines that allow white to be highlighted inside the brush stroke. Kasure is one of the most specific visual elements of shodo calligraphy (Goda, Nakamura, Kanō 28), managing to bring the balance between black and white inside the features of a character. The use of kasure in a calligraphic work can give an energetic look to the shape of the line, creating rhythm.

Rhythm is fundamental to calligraphy (Ishikawa 147, Flint Sato 12), and in this field it is regarded as "well-arranged dots and strokes forming a harmonious, beautiful, powerful and rhythmical calligraphic work" (Tingyou 85). Each style of writing (tensho, reisho, kaisho, gyōsho, sōsho and their variations) has a different rhythm (Flint Sato 12), the calligrapher being aware of the particularities of each style and how it employs the movement of the brush on paper. The rhythm is given by the constitution of the line and of the points that make up the characters of the calligraphic work and by the way in which these elements manage to activate the surrounding white space. Rhythm is a twodimensional aspect in a calligraphic work, manifesting itself at a macro level (the established rhythm of each writing style) and at a micro level (the inner rhythm of the personal style of the calligrapher, being uniquely transposed in each calligraphic work). Rhythm does not necessarily imply vivacity, as the lines can be graceful, delicate, calm or peaceful (Flint Sato 10), conveying the calligraphic work vitality from a multitude of perspectives. In order to generate rhythm, the calligrapher must be able to create harmonious lines within the composition of the work, deftly manoeuvring the brush and balancing the white space with the black of the ink.

Furthermore, similar to how the concept of emptiness does not have a negative meaning, the colour black in calligraphy does not acquire any negative connotations. The black ink is seen as "shadow" (Ishikawa 41), as it has the ability to give depth to the 
characters written through the various shades created. Moreover, in shodō, black does not indicate an absence of colour and calligraphy is not seen as monotonous compared to the art of painting where colour is essential for the transmission of the message. Shodo is not an art that highlights only the black and white contrast (Ishikawa 41), as it is considered that the black ink contains all the other colours and shades (Ishikawa 41, Sato 28). By choosing how wet the brush will be, how opaque the ink will look, the calligrapher can create countless meaningful variations of the black line. Moreover, sometimes gold tints can be used in the pattern engraved in the ink stick used to create the sumi ink, which, although not prominent enough to turn the final ink into gold ink, will give the calligraphic work small particles of light that can be later seen in the written characters.

Given the importance of the link between black and white in shodo, each calligrapher must learn how to balance the two in order to project their own individual view within the work. Although calligraphers respect this balance, some have tried to go beyond tradition in shodo, bringing colours to their works in various forms. In the following paragraphs we will analyse such a piece and observe the way in which modern use of colour blends in with traditional views on shodō.

\section{Case Study}

In order to analyse how shodo is an expression of the self while simultaneously challenging the boundaries of words and image by overcoming their limits, we aim to further discuss the calligraphic work (物の)哀 The beauty of simple and ephemeral things created by Rodica Frențiu. Rodica Frențiu is a contemporary Romanian calligrapher who has studied shodō in Japan, under the guidance of calligraphy master Nishida Senshū (1936-2015) and has been practicing the art for over 20 years. With numerous calligraphy expositions in both Romania and Japan, Rodica Frențiu brings calligraphy closer to the public through both works that follow the tradition of shodō, as well as works that bring modern twists to it. In 2017 she has received the Platinum Prize (Character Design section) at Connect the World. International Japanese Calligraphy Exhibition. Global Shodo@ Yasuda and in 2016 the Gold Prize (Brush Writing section) at the 1st International Japanese Calligraphy Exhibition, Yasuda Women's University in Hiroshima. 


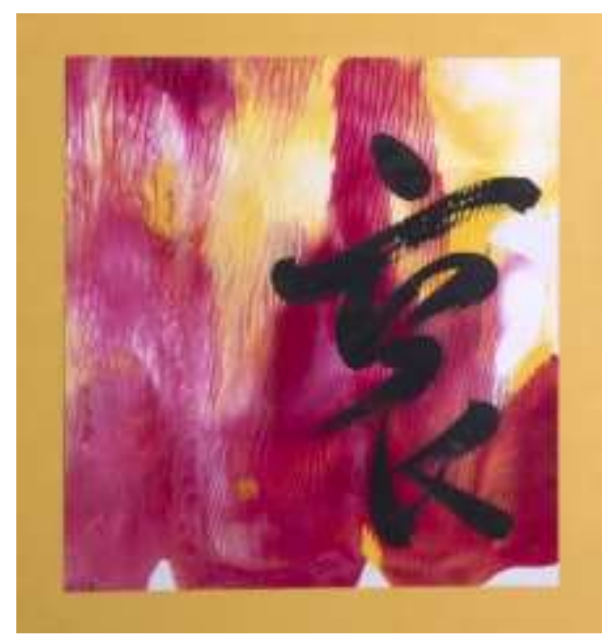

Fig. 1. (物の)哀 (mono no) aware The beauty of simple and ephemeral things Source: Rodica Frențiu. Caligrafia japoneză în memoria clipei. Cluj-Napoca: Presa Universitară Clujeană, 2021. page 75

The choice of interpreting this calligraphic work was made based on its ability to demonstrate how shodo manages to bring modern influences within a calligraphic work while maintaining its core traditional values. At a first glance, the receptor understands that the work in front of them does not fit into the traditional conventions of writing, because the background of the piece is abundant in colour. An art that prospered by showcasing the expressive value of the white of the paper and the black of the ink, shodo calligraphy is known for its chromatic simplicity. However, in spite of the apparent visual modesty of a work, shodō does not deny colour, but rather finds new ways to reflect it.

The work (物の)哀 The beauty of simple and ephemeral things deconstructs and then reconstructs the traditional perception of colour shodo, the calligrapher understanding the various properties of black and how it can be enhanced. The logogram calligraphed is part of the expression 物の哀れ(mono no aware), a concept that defines Japanese poetry, indicating how everything around us, by its very nature, can arouse deep feelings, humans being aware of the ephemeral nature of everything around them and coming to appreciate the beauty of everything that is transient (Ikegami, "Sign Conceptions in Japan" 1904). The title of the work makes this complex concept accessible to the public by including not only the哀 (aware) logogram that has been written, but the whole 物の哀れ (mono no aware) expression and an explanation of it: The beauty of simple and ephemeral things, helping the viewer understand the source and the meaning of the logogram within Japanese cultural and aesthetic values.

Through the act of challenging the traditional perception of colour, (物の)哀The beauty of simple and ephemeral things manages to fit in both the field of calligraphy and 
of painting. The colours used to construct the background are red and yellow, the warm and welcoming atmosphere they evoke creating an ideal framework for emphasizing the linguistic component, therefore visually supporting the concept of beauty of everything that is ephemeral.

An important aspect of the background's constitution is that the red and yellow do not completely cover the white of the paper. This is reminiscent of how in traditional calligraphy the white space left unwritten plays a role just as important as the space filled with black ink. Regardless of the writing style used, the syllabary or the logograms used, the calligrapher will always pay attention to the relationship between the written lines and yohaku. Accordingly, in (物の)哀 The beauty of simple and ephemeral things three layers of visual perception are created: that of the white of the paper, that of colour and that of the black ink. The role of colour is not to replace the white space, as yohaku is not an area that needs to be completed, finished, but to coexist with it, the two enhancing each other. For this reason, the areas where the white of the paper surfaces manage, together with the effect created by the colour, to highlight the black ink of the logogram哀.

The juxtaposition of the three visual layers allows the calligrapher to create a complex piece that enhances the writing of the logogram 衰 (aware). The logogram is placed on the right side, where the intersection between the white of the paper and the colour is most visible. Through this effect, the features of the哀logogram manage to overlap with the two layers, not just with the colour layer. The medium on which each feature is written reacts with the black of the ink, influencing the way in which black is perceived: in the case of the first two brush strokes, where the black ink has both colour and white in the background, a bright effect is created, accentuating the traces of the brush. As the logogram is completed, the last brushstrokes that have been written almost exclusively on a coloured background seem to dissolve into the colour, blurring the boundaries between the three visual layers present within the work.

Because paper - or any medium used for writing - reacts to every movement of the brush, calligraphy becomes a constant interaction between the calligrapher and the medium (Ishikawa 4). For this reason, the calligrapher understands the particularities of each type of background and writes each work according to how the medium can be enhanced. In (物の)哀 The beauty of simple and ephemeral things, the technique through which colour was used creates a texture that offers the reader not only a strong visual experience, but also a tactile one. The subtle effect of the colour has a powerful impact, 
the small details looking like vines that evoke the sensation of movement. Within the interplay between action and reaction of each calligraphic work, the way in which the brush strokes are integrated in the piece differs depending on the chosen background. Therefore, in (物の)哀 The beauty of simple and ephemeral things the kasure traces made by using a dry brush amplify the brightness effect in the case of the second and third brush strokes and support the tactile sensation of colour in the case of the last brushstrokes.

In writing the logogram 哀, the calligrapher used the semi-cursive gyōsho style, giving it expressiveness without compromising its legibility. The rounded, harmoniously curved lines maintain a graceful rhythm, the tempo of the brushwork being constant, without sudden changes of direction. The receptor can easily observe how the brush moved even when it has been lifted off the paper, the calligrapher therefore helping the public relive the creative act. In spite of the element of modernity created by the colourful background, reminiscent of both painting and Western calligraphic writing techniques, the gyōsho style in which the logogram was written maintains the tradition of shodo writing by circumscribing the work within one of the 5 main writing styles.

The link between modernity and tradition is not showcased only from a visual point of view, as the linguistic component also brings a significant contribution to this effect. Mono no aware, together with the concept of appreciating imperfection called wabi sabi, manages to illustrate the way in which Japanese aesthetics relate to nature and to everything that surrounds man. Mono no aware can be identified at several levels within Japanese culture, being present not only in poetry or literature, but also in calligraphy. Trying to bring writing closer to nature through the act of creation, shodō becomes a way of appreciating all that is ephemeral, including the spontaneous spark of inspiration that can lead to the creation of an exquisite calligraphic work.

Using colour to illustrate the pathos and the beauty of everything that's ephemeral creates an intense effect that reflects on a visual level the deep feelings that the linguistic component denotes. Oftentimes associated with passion, within the calligraphic work the colour red evokes the strong feelings experienced when contemplating the transient character of life and nature. In order to create visual balance, the colour yellow tempers the vigour of the colour red and helps create a smooth transition between red and the white of the paper. This interplay illustrates the way in which the visual and the linguistic components are intertwined, each revealing different facets of the other.

In the case of (物の)衰 The beauty of simple and ephemeral things, although the 
visual component is modern, under Western influences, the content of the linguistic component anchors the work within the traditional Japanese calligraphy established practices, the calligraphic work creating a graceful balance of old and new and becoming proof of the intersection between modernity and tradition. The effect achieved is not one of defying the conventions of tradition, but of paying homage to it through its delicate integration of modern painting techniques. Through the strong influence of the linguistic component, which is visually brought to the viewer's attention through the juxtaposition of three visual layers of representation, the work falls within the art of calligraphy, giving the audience the opportunity to see shodō from a new perspective.

By observing and analysing the (物の)哀 The beauty of simple and ephemeral things calligraphic work, the receptor manages to discover a strong connection between modernity and tradition, between past and present, but also between the vision of the calligrapher and the way in which these complex ideas were represented. Within apparent visual simplicity the receptor discovers techniques that denote a vast knowledge of the long calligraphic tradition and a deep understanding of how kanji have the ability to bring man closer to nature, while integrating impactful modern touches to the visual component.

\section{CONCLUSION}

Although shodo is to this day a form of art that requires rigorous training and discipline in order to master its techniques, calligraphers have been trying to use it as means to show their creativity and reflect their inner world through the black ink. As seen from the analysis of (物の)哀 The beauty of simple and ephemeral things, the modern elements that are brought into shodo are founded on the pillars of tradition, consequently trying to coexist with tradition, rather than replace it completely. As Japanese society is full of contradictions (Benedict 2) in the "dance" between modern and traditional, shodō becomes a "bridge" that connects the past and the present, harmonizing the old and the new.

Calligraphy, often defined as "beautiful writing" (Lovett 10) retains this aesthetically pleasing aspect in the case of shodō. However, although shodo can exhibit beautiful writing, this art goes beyond visual expression and extends it, giving a crucial role not to the written characters or logograms, but to the calligrapher and the receptor altogether. The essence of shodo is conferred neither by the word itself nor by its visual individual representation, but rather by the way in which the visual and linguistic components 
correlate in the revelation of the transcendent meaning. In this process, the way in which the calligrapher manages to illustrate their views and the way the receptor later manages to decode this message become the focal point of shodo, moving away from the perception that calligraphy is predominantly beautiful, orderly writing.

The shift from rigorous representation to an art of self-expression that started to take shape parallel to the changes within the writing system offers new opportunities to innovate certain traditional aspects of shodo. However, as seen from the analysis of (物の )哀 The beauty of simple and ephemeral things, the calligraphic work maintains its core values and is still part of the shodo art through the way in which other aspects of the piece have been portrayed: the meaning of the linguistic component, the materials used for writing or the way in which the calligraphic piece has been created. Although innovation may not be as radical as it was during the avant-garde period, it nonetheless allows the calligrapher to reflect their unique inner world through the written words and share it with the public.

Within (物の)哀 The beauty of simple and ephemeral things Rodica Frentiu manages to attribute new meanings to the yohaku of the work, by creating a piece that extends its visual component to three layers of representation. This technique allows the calligrapher to highlight the white space of the paper while using colour. The use of a partially coloured background does not thus negate the traditional practice of using only black and white for shodo, but rather extends it to new meanings that showcase the calligrapher's work. The yohaku has not been replaced by colour, it has rather integrated colour to create a delicate visual effect that frames and highlights the 哀 logogram. Through the juxtaposition of three layers, the brushstrokes of the logogram are accentuated by different types of luminosity: whereas the first strokes of 哀 are written on both white and coloured background, allowing the kasure to shine through, the last brushstrokes that have been written exclusively on colour create a dynamic and tactile effect that extends the principles of colour in shodo.

As proven by this work, when novelty factors are integrated within traditional practices, these new artistic techniques do not intend to completely replace the conventional techniques, but rather to accompany them by concomitantly using the ancient teachings of masters and modern touches that reflect the vision of the calligrapher. The work（物の）哀 The beauty of simple and ephemeral things brings together classic shodo techniques with influences of painting and Western calligraphy, showing the public a new perspective on the practice of shodo, as well as on the meaning of the logogram 哀 and the 
concept of mono no aware altogether. In this way, new currents and directions coexist, the calligrapher having at their disposal a series of means that they can apply to depict as accurately as possible what and how they feel towards the written logogram.

Shodō, in spite of being a centuries-old art form that still maintains its practice and core intact, is nonetheless a progressive art in which calligraphers have constantly attempted to bring their own vision into focus. This results in works that manage to honour the long-lasting calligraphic tradition, while reconstructing some of its techniques to better reflect the calligrapher's thoughts. Using one's creativity to reinvent certain aspects of the calligraphic tradition while maintaining and using the well-established writing techniques passed down from generation to generation allows calligraphers to freely express their thoughts when creating shodō art. The levels to which traditional or modern techniques have been used within a work can be a guiding factor that helps the receptor perceive the visual and the linguistic component of a work in a new light. This practice has great potential for contemporary Japanese calligraphy, as it allows practitioners to balance several seemingly contradictory aspects that define shodo: thorough planning and spontaneity, beauty and utility, discipline and creativity.

\section{WORKS CITED}

Abe, Masao. Zen and Western Thought. London: Macmillian, 1985.

Benedict, Ruth. The Chrysanthemum and the Sword. Tokyo: Charles E. Tuttle Company, 1994.

Bogdanova-Kummer, Eugenia. Bokujinkai. Japanese Calligraphy and the Postwar AvantGarde. Leiden-Boston: Brill, 2020.

Davey, H.E. The Japanese Way of the Artist. Albany: Michi Publishing, 2015.

Earnshaw, Christopher J. Sho. Japanese Calligraphy, 5th ed. Singapore: Tuttle Publishing, 2000.

Flint Sato, Christine. Japanese Calligraphy. The Art of Line \& Space. Osaka: Kaifusha Co Ltd., 1999.

Frențiu, Rodica. Caligrafia japoneză în memoria clipei. Cluj-Napoca: Presa Universitară Clujeană, 2021.

Goda, Yutaka, Nakamura, Tsuyoshi, Kanō, Masayoshi. “Example-based Design of Artistic 
Calligraphy Fonts". SCIS \& ISIS SCIS \& ISIS 2010. Japan Society for Fuzzy Theory and Intelligent Informatics, 2010. 28-33.

Hirakata, Seiichi et al., Zenkoku Daigaku Shodo Gakkai. Sho no koten to riron. Tokyo: Mitsumura Tosho, 2013.

Ikegami, Yoshihiko. "Homology of Language and Culture - A Case Study in Japanese Semiotics -". The Nature of Culture. Proceedings of the International and Interdisciplinary Symposium, October 7-11, 1986 in Bochum. Bochum: Studienverlag Dr. Norbert Brockmeyer, 1989. 388-403.

---. "Sign Conceptions in Japan". Sebeok Semiotics. A Handbook on the Sign-Theoretic Foundations of Nature and Culture, 2nd volume. Roland Posner, Klaus Robering, Thomas A. (ed.). Berlin, New York: Walter de Gruyter, 1998. 1989-1910.

Ishikawa, Kyuyō. Taction: The Drama of The Stylus in Oriental Calligraphy, Trans. Waku Miller. Tokyo: International House of Japan, 2011.

Lovett, Patricia. The Art \& History of Calligraphy, 2nd ed. China: The British Library Board, 2020.

Mukai, Shutaro. "Characters that Represent, Reflect and Translate Culture - in the Context of the Revolution in Modern Art". The Empire of Signs: Semiotic Essays on Japanese Culture. Yoshihiko, Ikegami. Amsterdam: John Benjamin, 1991. 59-83.

Murase, Miyeko. The written image. New York: The Metropolitan Museum of Art, 2002.

Nishitani, Keiji. Religion and Nothingness. Trans. Jan Van Bragt. United States of America: University of California Press, 1900.

Robinson, Andrew. Istoria Scrisului. Alfabete, hieroglife si pictograme, Trans. Mihnea Gafița. București: ART, 2009.

Sato, Shozo. Shodo. The Quiet Art of Japanese Zen Calligraphy. United States of America: Tuttle Publishing, 2013.

Seeley, Christopher. A History of Writing in Japan. Honolulu: University of Hawai'i Press, 2000.

Suzuki, Yūko. An Introduction to Japanese Calligraphy. Lower Valley Road: Schiffwe Publishing Ltd., 2016.

Tingyou, Chen. Chinese Calligraphy. China: China Intercontinental Press, 2003. 
Wunenburger, Jean-Jacques. Filozofia imaginilor. Iași: Polirom, 2004. 